\title{
Serological detection of Anaplasma marginale, Babesia bovis and Babesia bigemina in beef cattle of the northern and central-western regions of Brazil
}

\author{
Detecção sorológica de Anaplasma marginale, Babesia bovis E \\ Babesia bigemina em bovinos de corte das regiões Norte e Centro \\ Oeste do Brasil
}

\author{
Jenevaldo Barbosa da Silva ${ }^{1 *}$; Matheus Dias Cordeiro²; Bruna Sampaio Martins \\ Land Manier²; Jaqueline Rodrigues de Almeida Valim²; Henrique dos Anjos \\ Bomjardim $^{3}$; Adivaldo Henrique da Fonseca ${ }^{4}$; José Diomedes Barbosa ${ }^{5}$
}

\begin{abstract}
The objective of this study was to assess the occurrence of antibodies against Anaplasma marginale, Babesia bovis and Babesia bigemina in beef cattle of the northern and central-western regions of Brazil. A total of 1703 blood samples were collected from cattle from 100 farms distributed among 37 municipalities in the states of Mato Grosso, Pará and Tocantins. The search for antibodies was conducted using an indirect enzyme-linked immunosorbent assay (ELISA), and antibodies were observed for $B$. bovis, B. bigemina and A. marginale in cattle from Mato Grosso, Tocantins and Pará at rates of 99\%, $90 \%$ and $41 \% ; 99 \%, 70 \%$ and $52 \%$; and $97 \%, 97 \%$ and $75 \%$, respectively. The results show that the analyzed regions exhibit enzootic stability for infection with $B$. bovis and B. bigemina, whereas the same result was not observed with A. marginale.
\end{abstract}

Key words: Anaplasmosis, Babesiosis, beef cattle, Northern Region, Central-Western Region

\section{Resumo}

O objetivo deste estudo foi verificar a ocorrência de anticorpos contra Anaplasma marginale, Babesia bovis e Babesia bigemina em bovinos de corte das regiões Norte e Centro Oeste do Brasil. Foram selecionadas randomicamente 1703 amostras de sangue de bovinos em 100 propriedades rurais distribuídos em 37 municípios dos estados do Mato Grosso, Pará e Tocantins. A pesquisa de anticorpos foi realizada por meio do Ensaio de Imunoadsorção Enzimático (ELISA) Indireto. A ocorrência de anticorpos observada para B. bovis, B. bigemina e A. marginale em bovinos dos estados do Mato Grosso, Tocantins e Pará foi $99 \%, 90 \%$ e $41 \%$; $99 \%, 70 \%$ e $52 \%$ e $97 \%, 97 \%$ e $75 \%$, respectivamente. Os resultados mostram que as regiões analisadas apresentam estabilidade enzoótica para a infecção por B. bovis e B. bigemina, não sendo observado o mesmo para Anaplasma marginale.

Palavras-chave: Anaplasmose, Babesiose, gado de corte, Região Norte, Região Centro-Oeste

1 Discente, Dept ${ }^{\circ}$ de Patologia Veterinária, Faculdade de Ciências Agrárias e Veterinárias, Universidade Estadual Paulista, FCAV/ UNESP, Jaboticabal, SP, Brasil. E-mail: jenevaldo@hotmail.com

2 Discentes, Dept ${ }^{\circ}$ de Epidemiologia e Saúde Pública, Universidade Federal Rural de Rio de Janeiro, UFRRJ, Seropédica, RJ, Brasil. E-mail: mathcordeiro@hotmail.com; brunalandmanier@yahoo.com.br; jaquelinevalim@yahoo.com.br

3 Discente, Dept ${ }^{\circ}$ de Ciência Animal, Universidade Federal do Pará, UFPA, Castanhal, PA, Brasil. E-mail: henriqueanjos18@ hotmail.com

4 Prof., Dept ${ }^{\mathrm{o}}$ de Epidemiologia e Saúde Pública, Universidade Federal Rural de Rio de Janeiro, UFRRJ, Seropédica, RJ, Brasil. E-mail: adivaldo@ufrrj.br

5 Prof., Dept ${ }^{\circ}$ de Ciência Animal, Universidade Federal do Pará, UFPA, Castanhal, PA, Brasil. E-mail: diomedes@ufpa.br Author for correspondence 
The states of Mato Grosso, Pará and Tocantins are part of the Amazônia Legal, which is a region of national and international economic, social and environmental importance. The region has a cattle population of approximately 73 million heads (34\% of the total Brazilian herd) on more than 61 million hectares of natural or cultivated pastures; thus, cattle raising has been a major focus of the debate over sustainable development of the Amazon region (BRAZIL, 2012).

The Anaplasmataceae Anaplasma marginale and protozoans Babesia bigemina and Babesia bovis are etiological agents that cause bovine anaplasmosis and babesiosis in both tropical and subtropical countries (MCCOSKER, 1981; KOCAN et al., 2010). Babesiosis is a disease transmitted by the tick Rhipicephalus microplus, whereas anaplasmosis can be transmitted by ticks and bloodsucking diptera (MCCOSKER, 1981; KOCAN et al., 2010). Both babesiosis and anaplasmosis are associated with large economic losses because they result in decreases in milk production and weight gain and expenditures associated with control and prophylaxis and may cause death in susceptible animals (BARROS et al., 2005). The three agents A. marginale, $B$. bovis and B. bigemina are obligate intracellular parasites of erythrocytes. The association of babesiosis with anaplasmosis can cause symptoms such as anemia, jaundice, fever, anorexia, lethargy, ataxia, pale mucosa, tachypnea, hemoglobinuria, muscle tremors and tooth gnashing in cattle (VIDOTTO; MARANA, 1999; KOCAN et al., 2010).

The diagnosis of babesiosis and anaplasmosis is traditionally performed by the detection of infectious agents in stained blood smears using light microscopy. However, at subclinical and chronic stages, this method is not sensitive enough to detect these agents (TERKAWI et al., 2012). Thus, a variety of serological techniques have been applied to the diagnosis of infection with Babesia spp. and A. marginale (KOCAN et al., 2010).
Because of its practicability and high sensitivity, the indirect ELISA method has been used in seroprevalence studies for these agents and considered promising for the diagnosis of babesiosis and anaplasmosis (MACHADO et al., 1997; TERKAWI et al., 2012). Thus, this diagnostic technique has been used in recent decades and is considered a breakthrough in terms of sensitivity, specificity, standardization and reproducibility (MACHADO et al., 1997). The objective of this study was to detect the presence of antibodies against A. marginale, B. bigemina and $B$. bovis in beef cattle in the northern and central-western regions of Brazil.

A total of 1703 blood samples were collected from 32 farms spanning 15 municipalities of Mato Grosso State (Tangará, Denise, Nova Marilândia, São Felix do Araguaia, Santa Cruz do Xingu, Castanheira, Primavera do Leste, Brasnorte, Canarana, Espigão do Norte, Campo Novo, Vila Rica, Juína, Luciara and São José do Xingu), 42 farms across eight municipalities of Pará State (Marabá, Itupiranga, Xinguara, Rio Maria, Água Azul do Norte, Curionópolis, Santa Maria das Barreiras and Bannach) and 26 farms spanning 14 municipalities of Tocantins State (Miranorte, Bernardo Sayão, Porto Nacional, Santa Fé do Araguaia, Alvorada, Talismã, Bandeirantes do Tocantins, Colinas, Divinópolis do Tocantins, Araguanã, Pium, Miracema, Couto Magalhães and Gurupi). A minimum of two and maximum of four farms were selected per municipality. In each farm, samples were randomly a collected from a minimum of five and maximum of 50 animals.

The animals evaluated in this study were female Nelore cattle (Bos indicus) of approximately three years of age. The search for immunoglobulin $\mathrm{G}$ (IgG) antibodies against $A$. marginale, $B$. bigemina and $B$. bovis was performed using an indirect enzyme-linked immunosorbent assay (ELISA) according to Machado et al. (1997). Sera from cattle with high titers of antibodies to the tested agents were used as positive controls. Sera from newborn 
cattle, which had not ingested colostrum and had tested negative in a previous ELISA, were used as negative controls. The cutoff point was calculated based on the results of sera from 30 negative animals assessed through a receiver operating characteristic (ROC) analysis using the statistical software
MedCalc (version 11.4; http://www.medcalc.be) (TERKAWI et al., 2012).

The absolute results for the presence of IgG antibodies against $A$. marginale, $B$. bovis and $B$. bigemina in Nelore beef cattle in the states of Mato Grosso, Pará and Tocantins are presented in Table 1.

Table 1. Serological detection of Anaplasma marginale, Babesia bovis and Babesia bigemina in Nelore beef cattle from the states of Mato Grosso, Pará and Tocantins, Brazil, 2012.

\begin{tabular}{lcccc}
\hline & Total & Anaplasma marginale & Babesia bovis & Babesia bigemina \\
\cline { 2 - 5 } Mato Grosso & 516 & 212 & 511 & 463 \\
Pará & 679 & 506 & 661 & 661 \\
Tocantins & 508 & 267 & 507 & 355 \\
\hline
\end{tabular}

Among the 1703 bovine serum samples analyzed from the states of Mato Grosso, Pará and Tocantins, $57.84 \% \quad(985 / 1703), 98.59 \% \quad(1679 / 1703)$ and $86.85 \% \quad(1479 / 1703)$ tested positive for $A$. marginale, B. bovis and B. bigemina, respectively.

Of the hemoparasites tested by indirect ELISA in the state of Mato Grosso, B. bovis was the most prevalent $(99.03 \%)$, followed by $B$. bigemina (89.73\%) and A. marginale (41.09\%). In cattle from the state of Pará, B. bovis and B. bigemina had the highest prevalence (97.3\%), followed by A. marginale $(74.52 \%)$. In the state of Tocantins, $B$. bovis had the highest frequency of positive results (99.89\%), followed by B. bigemina (69.88\%) and A. marginale (52.56\%). Thus, the individual results indicated that multiple infections by all three agents occurred, with $200(38.76 \%)$ infected animals from Mato Grosso, 494 (72.75\%) infected animals from Pará and 247 (48.62\%) infected animals from Tocantins.

Antibodies against the agents that cause babesiosis and anaplasmosis in cattle had previously been detected in the five regions of the country (VIDOTTO; MARANA, 1999; SOUZA et al., 2000a; 2000b; BARROS et al., 2005), and variations in prevalence may have been caused by climate and/or soil characteristics specific to each location. Temperature and humidity are important factors for the development of the tick $R$. microplus, a common vector of the pathogens that affects the dynamics of transmission in the analyzed regions. Barros et al. (2005) assessed the prevalence of Babesia spp. in cattle from two regions with distinct epidemiological characteristics in the semiarid region of Bahia and associated the observed enzootic stability to agents with climatic interactions as well as to the biological cycle of the vector. The semiarid region is enzootically stable to $B$. bigemina and $B$. bovis, and it receives greater mean rainfall than the region where $B$. bigemina and $B$. bovis prevalence is considered unstable.

The frequency of positive tests for B. bovis from the three states addressed in this study is consistent among the states as well as with studies performed in different regions of Brazil (BARROS et al., 2005; D'ANDREA et al., 2006; GUEDES-JUNIOR et al., 2008; TRINDADE et al., 2010). The prevalence of $B$. bigemina and $A$. marginale observed at the state level in Tocantins was lower than the prevalence observed in the Araguaína region of Tocantins according to Trindade et al. (2010) (99.2\%) and Trindade et al. (2011) (89.9\%).

The frequency of antibodies to A. marginale in the states of Mato Grosso, Tocantins and Pará was 
relatively low compared with what was observed in other studies conducted in Brazil (ANDRADE et al., 2001; BARROS et al., 2005; TRINDADE et al., 2011). The state of Mato Grosso has the lowest A. marginale prevalence $(41.09 \%)$, and the value is below the prevalence observed in the state of Tocantins (52.56\%); however, the prevalence was higher in the state of Pará than in the other states evaluated in the present study $(74.52 \%)$. Limited studies have investigated the prevalence of $A$. marginale in the northern regions of the country. The results of the present study showing the presence of antibodies for A. marginale in the state of Pará indicate that the region is generally enzootically stable, which is inconsistent with the results for buffalo populations in Pará (SILVA et al., 2014) and the other studied states.

The prevalence recorded for B. bigemina in Tocantins indicates that this state is an unstable region for this agent, whereas the prevalence values for $B$. bovis indicate that the three evaluated states are enzootically stable for this agent. Because of the considerable rate of seropositive results, the evaluated region is at risk from introduced nonadapted animals or animals from areas of enzootic instability for bovine anaplasmosis and babesiosis. In this study, the animals sampled in the three states were beef cattle destined for export. Therefore, one hemoparasitosis outbreak could produce a significant economic loss.

Zebu cattle present greater resistance to ticks compared with Bos taurus breeds (reference??); therefore, Zebu cattle are less likely to be exposed to ticks infected with Babesia spp. and A. marginale. Thus, enzootic instability would be expected for Babesia spp. and A. marginale in this breed (D'ANDREA et al., 2006).

Only Nelore cattle were tested in this study; therefore, variations in the prevalence of hemoparasites occurring among the evaluated states could be explained by the rate of infection by ticks and/or rate of herd inoculation by infected ticks.
The frequency of positive tests for $A$. marginale in cattle may be influenced by the mechanical transmission that occurs with blood-sucking insects and fomites (KOCAN et al., 2010). Thus, evaluating the transmission of this rickettsia infection using the rate of positive tests for $A$. marginale in the population of ticks and bloodsucking flies may be a more reliable alternative to identifying the likely vectors of the agents in the studied regions. In studies on the epidemiology of these three agents in Brazil, a small population of ticks has been observed to maintain the rate of inoculation by hemoparasites as well as their enzootic stability.

Based the results obtained in this study, B. bovis and $B$. bigemina have similar epidemiological profiles, which may be related to their transmission by a common vector. Although $A$. marginale is also transmitted mechanically, certain areas exhibit a low serological response, indicating instability for this agent in the region. Because these agents are pathogenic and prone to outbreaks, studies investigating their transmission mechanisms should be conducted.

\section{Acknowledgements}

We are grateful to Dra. Rosangela Zacarias Machado by kindly supplied the antigen used. We also thank the Coordination for the Improvement of Higher Level of Education Personnel (CAPES) for financial support.

\section{References}

ANDRADE, G. M.; VIDOTTO, O.; VIDOTTO, M. C.; YOSHIHARA, E. Seroprevalence of Anaplasma marginale in dairy cattle and, studies on the dynamics of natural infection of Holstein calves in southern Brazil. Semina: Ciências Agrárias, Londrina, v. 22, n. 2, p. 155159, ju./dec. 2001.

BARROS, S. L.; MADRUGA, C. R.; ARAÚJO, F. R.; MENK, C. F.; ALMEIDA, M. A. O.; MELO, E. P.; KESSLER, R. H. Serological survey of Babesia bovis, Babesia bigemina, and Anaplasma marginale antibodies in cattle from the semi-arid region of the state of Bahia, 
Brazil by enzyme-linked immunosorbent assays. Memórias do Insituto Oswaldo Cruz, Rio de Janeiro, v. 100 , n. 6, p. 513-517, oct. 2005.

BRASIL. Dados de rebanho bovino e bubalino do Brasil. Brasília: BINAGRI, 2012. Disponível em: <www. agricultura.gov.br/arq_editor/file/Dados de rebanho bovino e bubalino do Brasil_2012.pdf>. Acesso em:25 mar. 2014.

D’ANDREA, L. A. Z.; SARTOR, I. F.; MADRUGA, C. R.; FREITAS, S. B. Z.; KROLL L. B.; KRONKA, S. N. Condição imunológica de bovinos das raças Holandesa e Nelore frente a Babesia bovis e B. bigemina em duas regiões do Estado de São Paulo. Pesquisa Veterinária Brasileira, Rio de Janeiro, v. 26, n. 2, p. 74-78, 2006.

GUEDES JUNIOR, D. S.; ARAÚJO, F. R.; SILVA, F. J. M.; RANGEL, C. P.; BARBOSA, J. D.; FONSECA, A. H. Frequency of antibodies to Babesia bigemina, Babesia bovis, Anaplasma marginale, Trypanosoma vivax and Borrelia burdgorferi in cattle from the northeastern region of the state of Pará, Brazil. Revista Brasileira de Parasitologia Veterinária, Jaboticabal, v. 17, n. 2, p. $105-$ 109, 2008.

KOCAN, K. M.; LA FUENTE, J. de; BLOUIN, E. F.; COETZEE, J. F.; EWING, S. A. The natural history of Anaplasma marginale. Veterinary Parasitology, Amsterdam, v. 7, n. 24, p. 95-107, 2010.

MACHADO, R. Z.; MONTASSIER, H. J.; PINTO, A. A.; LEMOS, E. G.; MACHADO, M. R. F.; VALADÃO, I. F. F.; BARCI, L. G.; MALHEIROS, E. B. An enzymelinked immunosorbent assay (ELISA) for the detection of antibodies against Babesia bovis in cattle. Veterinary Parasitology, Amsterdam, v. 71, n. 1, p. 17-26, 1997.

McCOSKER, P. J. The global importance of babesiosis. In: RISTIC, M.; KRIER, J. P. (Ed.). Babesiosis. New York: Academic Press, 1981. p. 1-24.

SILVA, J. B.; SANTOS, P. N. dos; CASTRO, G. N. S.; FONSECA, A. H.; BARBOSA, J. D. Prevalence Survey of Selected Bovine Pathogens in Water Buffaloes in the North Region of Brazil. Journal of Parasitology Research, Cairo, v. 2014, n. 1, p. 1-4, 2014.
SOUZA, J. C. P.; SOARES, C. O.; MASSARD, C. L.; SCOFIELD, A.; FONSECA, A. H. Soroprevalência de Anaplasma marginale em bovinos na mesorregião Norte Fluminense. Pesquisa Veterinária Brasileira, Seropédica, v. 20, n. 3, p. 97-101, 2000a.

SOUZA, J. C. P.; SOARES, C. O.; SCOFIELD, A.; MADRUGA, C. R.; CUNHA, N. C.; MASSARD, C. L.; FONSECA, A. H. Soroprevalência de Babesia bigemina em bovinos na mesorregião Norte Fluminense. Pesquisa Veterinária Brasileira, Seropédica, v. 20, n. 1, p. 26-30, jan./mar. 2000b.

TERKAWI, M. A.; ALHASANA, H.; HUYENA, N. X.; SABAGH, A.; AWIER, K.; CAO, S.; GOO, Y. K.; ABOGEA, G.; YOKOYAMA, N.; NISHIKAWAA, Y.; KALB-ALLOUZ, A. K.; TABBAB, D.; IGARASHIA, I.; XUANA, X. Molecular and serological prevalence of Babesia bovis and Babesia bigemina in cattle from the central region of Syria. Veterinary Parasitology, Amsterdam, v. 187, n. 1-2, p. 307-311, 2012.

TRINDADE, H. I.; ALMEIDA, K. S.; SOUSA, M. G.; TEIXEIRA, M. C. A.; MACHADO, R. Z.; BATISTA, M. C. S.; BATISTA, E. K. F. Frequência de Anaplasma marginale em bovinos da região de Araguaína, estado de Tocantins, Brasil. Ciência Animal, Goiânia, v. 21, n. 2, p. 119-125, 2011.

TRINDADE, H. I.; SILVA, G. R.; TEIXEIRA, M. C.; SOUSA, M. G.; MACHADO, R. Z.; FREITAS, F. L.; ALMEIDA, K. S. Detection of antibodies against Babesia bovis and Babesia bigemina in calves from the region of Araguaína, state of Tocantins, Brazil. Revista Brasileira de Parasitologia Veterinária, Jaboticabal, v. 19, n. 3, p. 169-173, jul./sept. 2010.

VIDOTTO, O.; MARANA, E. R. M. Anaplasmose bovina: aspectos epidemiológicos, clínicos e controle. Semina: Ciências Agrárias, Londrina, v. 20, n.1, p. 98106, 1999. 
